\title{
Metropolis as the Highest Form of Space Organisation
}

\author{
Agnieszka Humen-Kłyza \\ Wrocław University of Economics, \\ Faculty of Economics, Management and Tourism in Jelenia Góra, \\ Nowowiejska Street 3, 58-500 Jelenia Góra \\ e-mail: agnieszka.humen@gmail.com
}

\begin{abstract}
There has been a growing interest in metropolises due to their ability to, among other things, change the paradigm of economy. The aim of this article is to present the most essential aspects of the concept of a metropolis as a spatial and structural form. Special importance is given to the analysis of the process determining its establishment - the process of metropolitanization - with regard to the factors which trigger the process itself and to its environmental impact. The theoretical part of the study refers to the conceptual dissonance, which occurs in the source literature. Discussed will be mainly the concepts of the development of a metropolis, its definition frames, immanent features differentiating it from other cities, as well as the functions it serves in its environment.
\end{abstract}

\section{Introduction}

Metropolises date back to the times of ancient Greece. City-states of those times founded citycolonies, for which they served as mother-cities, in other words - metropolises. A similar function for the inhabitants of lands conquered by the English was performed by England, London in particular. Currently, the notion of a metropolis carries different meaning metropolises are places sending impulses for the development aimed at both the nearest communes and neighbouring metropolitan cities. Emerging metropolises are the evidence for the evolution of contemporary cities. Owing to their creative assets based on science, culture and technology, leading world and European metropolises generate economic increase and development, being hosts for the representatives of the so-called creative class. This capital makes them an attractive business location for international corporations, companies offering worldwide services or capital market centres [9]. Furthermore, it confirms the existence of supra-territorialization of economic, social and cultural links on a global scale [10].

The objective of this article is to present the most significant concepts concerning the establishment, development and functioning of metropolises. The cause-and-effect characterization of the metropolitanization process shall provide a starting point for a further discussion. The theoretical part explores the notion of the conceptual dissonance, which occurs in the source literature. Discussed will be mainly the concepts of the development of a metropolis, its definition frames, immanent features differentiating it from other cities, as well as functions it serves in its environment.

For the purposes of this article a desk research method in the form of a source literature analysis will be used. 
There are several processes simultaneously affecting contemporary economy and determining its character. Apart from globalization, internationalization, liberalization and the process of despatialization, a growing attention has been recently paid to the process of metropolitanization [10]. It dominates current trends in reorganizing the existing settlement system in Europe [12]. Metropolises, which arise as a result of it, create innovation- and knowledge-friendly environment, which is indispensable in terms of achieving high levels of global socio-economic growth [6]. According to S. Korenik "Contemporary economy, based mainly on knowledge and creation of spatial economic networks, evokes significant but natural accumulation of any chosen socio-economic activities and phenomena. It results from an unparalleled concentration of the latest businesses and scientific and economic institutions in big metropolitan cities." [5]

Preceded by urbanization, suburbanization, deurbanization and relative reurbanization, metropolitanization is the fifth and the last phase of a city development. It leads to the emergence of a new spatial structure and, consequently, change in the prevailing relation between the centre and the surroundings [5]. As a result, centres of local, continental and even global significance turn up, and some large cities take over executive functions in economy management. Metropolitanization is associated with internationalization of urban functions, indicated by the free trade of goods and services and international cooperation [3]. T. Markowski claims that metropolitanization is a functional - not morphological - notion, which implies the necessity to fulfill particular functions, as illustrated in Figure 1. It presents the metropolitanization process as a dynamic phenomenon, aiming at increasing the effectiveness of big cities and their surrounding areas [5].

It is important to emphasize that the metropolitanization process does not exclude urbanization seen as the process of cities emergence and the development of urban lifestyle connected with the economic growth. While urbanization is continuously in progress, it has been dominated by the metropolitanization process. It results in changes in the social and urban fabric not only within a metropolis, but also in the dependent regions. Hence, the problems with socio-economic space discontinuity lead to the polarization of the development and in consequence to the constant reinforcement of central places and diminution of the role of the regional base. The latter is limited solely to providing inhabitants of metropolises with residential and recreational facilities [9]. Therefore, the process of metropolitanization shall be considered twofold: as an emergence of mega-centre network of metropolitan cities serving global functions, and as freeing metropolises from the dependency on their regional base in order to establish contacts within the global mega-centre network of cities [12].

The causes underlying the metropolitanization phenomenon are as follows:

- changes in the nature of the social needs resulting from a higher standard of living;

- widespread use of individual car transportation;

- better efficiency of public communication;

- internationalization of service activities and strengthening links between metropolitan areas to contribute to the relations with regions;

- substantial social and ethnic differences;

- great mobility;

- changes in occupational structure of societies caused by servitization of economy;

- globalization; 
- excellence of services, institutions and amenities;

- social fragmentation and polarization reflected by, for instance, the emergence of the socalled metropolitan class;

- technical, economic, social, political and cultural innovation capability;

- uniqueness of place;

- spread of urbanization to rural and suburban areas. [12]

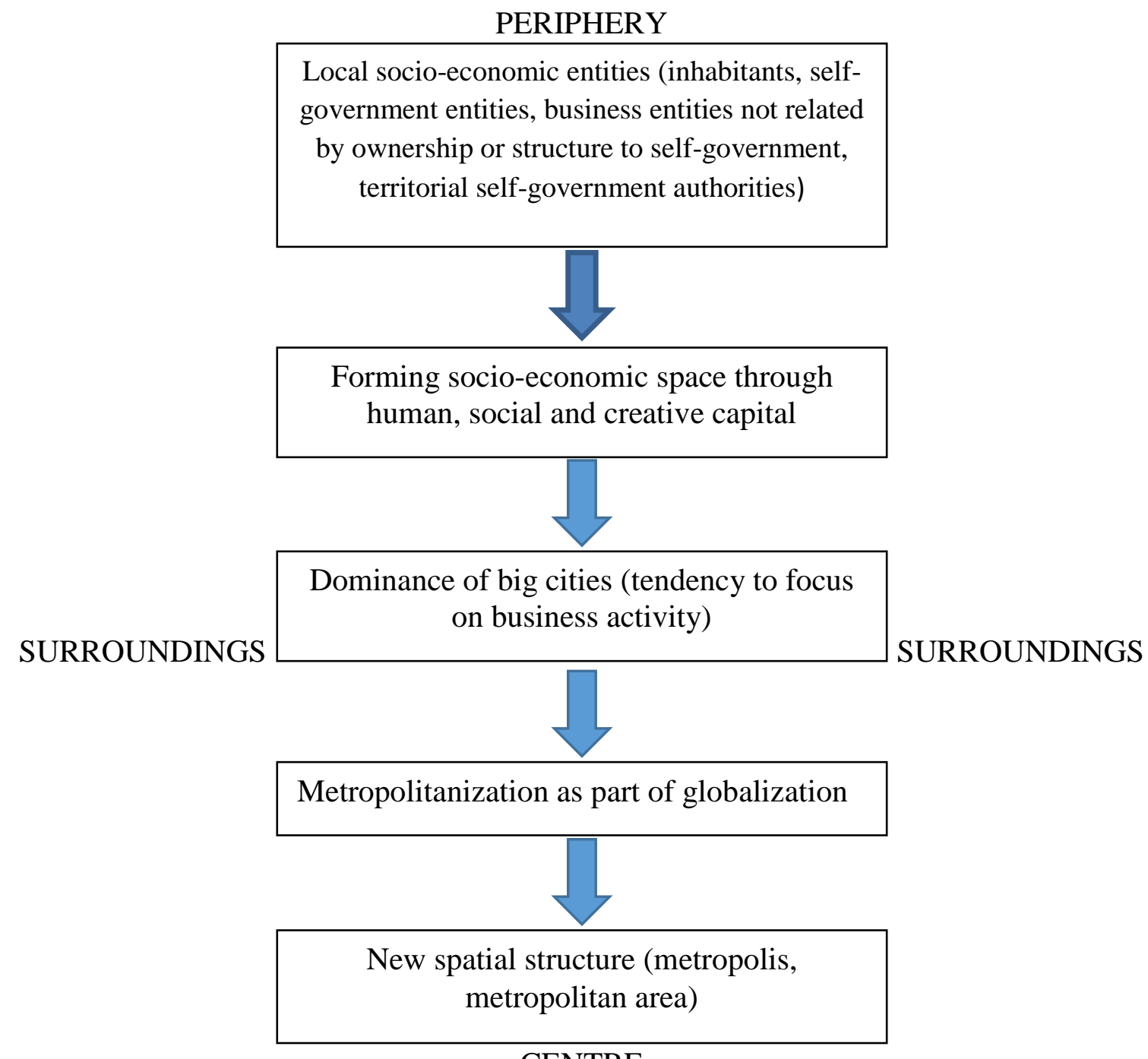

Source: [4, p. 181]

\section{CENTRE}

Fig. 1: Metropolitanization process of socio-economic space

The process of urbanization is accompanied by transformations in the field of creating space, within a society and in the cultural sphere. These transformations involve the parallel occurrence of the following phenomena:

- accumulation of economic growth and workplaces in the network of international connections;

- despecialization of regional and urban economy determined by visible domination of the service sector; 
- increased discrepancies between centres and periphery, and more frequent horizontal relations between metropolises;

- increased discrepancies between regions and cities, as well as within metropolitan areas, growing time and space differences between entities. [3]

\section{The notion and characteristics of a metropolis}

Defining a metropolis is both an essential and difficult enterprise. The importance of such a definition is indicated by the growing significance of metropolises in, for instance, strategic documents of the European Union - the policy initiatives of the Lisbon Strategy have been mainly undertaken in metropolitan areas, with metropolises being at their core. However, the notion of a metropolis has been used arbitrarily. There is a tendency to associate metropolises with cities of relatively large populations, or to emphasize only selected metropolitan functions. From the review of definitions presented below it will become evident that both of these approaches are erroneous [8].

Not every big city deserves to be called a metropolis. The key qualitative indicators which have to be taken into consideration include the high quality technical infrastructure, a developed sector of high order services, innovation capability, and the uniqueness of the place. Big cities which do not comply with the above mentioned criteria are called "megacities". This term, however, refers to the cities located in the developing countries.

The notion of a metropolis as presented in the source literature is frequently associated with the concept of a world city (proposed by J. Friedmann) and with the developed and modified concept of a global city (proposed by S. Sassen) [11]. Both concepts prove the predominant importance of cities in contemporary global economy as well as in economies of particular countries. According to them, the importance of cities is based less and less on their central functions towards the region, as it depends more and more on performing supra-regional managerial functions [9]. Other researchers, including B. Derudder, claim these to be two different concepts. The first accentuates the concentration of control functions in the city. On the other hand, S. Sassen emphasizes the key role of companies offering advanced information services in the economy of global cities [11]. Another view on a metropolis is presented by M. Castells. According to his theory, a metropolis of the $21^{\text {st }}$ century is an information city characterized by the dominant space of flows in its industrial space. This space, described as the new industrial space, is highly innovative and constitutes an inherent part of modern economy [9].

Leaving aside the above discussion, it is possible to define a metropolis as the final stage of a city-agglomeration development. A metropolis is a mother-city in which new ideas emerge and crucial decisions of regional, national and international importance are made [7]. The minimum number of its inhabitants amounts to 500,000 [3]. Still being a city, it is characterized from the $21^{\text {st }}$ century perspective, which values the growing diversity and interdependence of the urban cultural space and its links with local and global economy. By virtue of an impact on creating and spreading information and due to the circulation of international capital, the role of a metropolis is on the rise [9]. This, in turn, is reflected in the social structure, among others in a high level of permanent employment in the public sector and in large private enterprises [7].

One may look at a metropolis through the prism of its functions and in morphological terms.

European metropolises may be distinguished in respect of the flow of technologies, capital, knowledge, symbols, and concepts. They carry out the following functions:

- they take in foreign production factors, investments, labour force, goods and services; 
- they host foreign companies, headquarters and subsidiaries of international enterprises, banks, non-government, academic and educational institutions, schools and universities attended by a vast number of foreign students, and also diplomatic posts;

- they export production factors, enterprises, banks, and other socio-economic, cultural and academic institutions;

- they have direct connections with the world through the network of transport and communication, the system of motorways, fast rail transport, international airports;

- having an expanded "infostructure", they communicate intensively with foreign countries through postal and telecommunication services, and encounter with the flow of tourists;

- they offer a well-developed service sector aimed at foreign customers - convention and exhibition centres, luxurious hotels, international schools, high standard office space, international law firms, international academic institutions;

- they accommodate mass media with international coverage which operate within their borders;

- they regularly hold various international events - conventions, exhibitions, festivals, sport and artistic events presenting foreign theatrical groups;

- they host national and regional institutions of international recognition working on foreign relations, for instance, various associations and sports clubs;

- their branches in different cities abroad practise paradiplomacy via municipal and private institutions (for instance, membership in international organisations, such as city twins associations, metropolitan associations, etc.);

A synthesis of characteristic features of a metropolitan centre includes:

- carrying out particular service functions towards the national territory or, in large countries - a part of the territory, province or in macro-regional terms. Service functions concern specialized administration, finance and management of corporations, judicial system, education and culture. The influence on economy is not so unequivocally beneficial - some situations may trigger processes of "eluting", draining regions, which occur with different intensity and consist of e. g. migration of young, educated staff and attracting majority of investments;

- inducting growth and qualitative changes in the immediate surroundings, in the neighbouring urban centres, and an emergence of new cities, international and global connections [13].

Apart from the functional aspect of a metropolis, national literature highlights also the quantitative criterion. According to the definition by B. Jałowiecki, a metropolis is "a large urban centre with a population of approximately 1 million people, distinguished by the excellence of services and infrastructure, innovation in all essential fields of its activity, and the character of a place" [2]. However, J. Słodczyk observes that "although urban centres as metropolises are distinguished by a considerable concentration of population, it is not entirely justifiable to determine the metropolitan character of a city by the number of people living in it. It is worth noticing, though, that the appropriate level of population is required to accumulate large-city functions". He claims that when appointing a potential metropolis one should not regard the number of its inhabitants as a criterion, but as a prerequisite for identifying a metropolis. He also states that it is difficult to determine the level of population which would be necessary to consider an urban centre to be a metropolis [4]. A similar point 
of view is presented by J. Pasek. According to him, the character of a city is determined not by its size, but by the developed metropolitan functions, which are ascribed solely to metropolises. Metropolitan or large-city functions are specialized ones. Their development is influenced by the resources either available in metropolises, or possible to be outsourced, which consist of mobile capital, including social capital (highly educated, specialized and experienced executive staff and workforce) [1]. These functions exist in the following fields:

- politics and administration - various administrative institutions located in a metropolis generate contacts between the region and its surroundings, and considerably increase its openness to the surroundings;

- economy and finance - metropolises constitute major economic and financial centres of regions, they arrange regional labour, services and property market;

- tourism, recreation and entertainment - metropolitan cultural space combined with the natural beauty of the region is crucial for the development of a tourism sector of national and international ranges;

- communication and telecommunication - metropolises are national and international communication and information centres; ICT (information and communications technology) accessibility of the region and its functioning in global information networks integrates regionality with globality;

- higher education, research and development - knowledge, innovations, scientific works and patents are all products of a metropolis; the majority of them are various intellectual products with the sphere of influence exceeding the region;

- high culture and mass media - metropolises act as multimedia centres and they enable social communication, establish a sense of regional identity and strengthen the contact between the region and the world [12].

Figure 2 illustrates the functions of metropolises and their mutual connections.

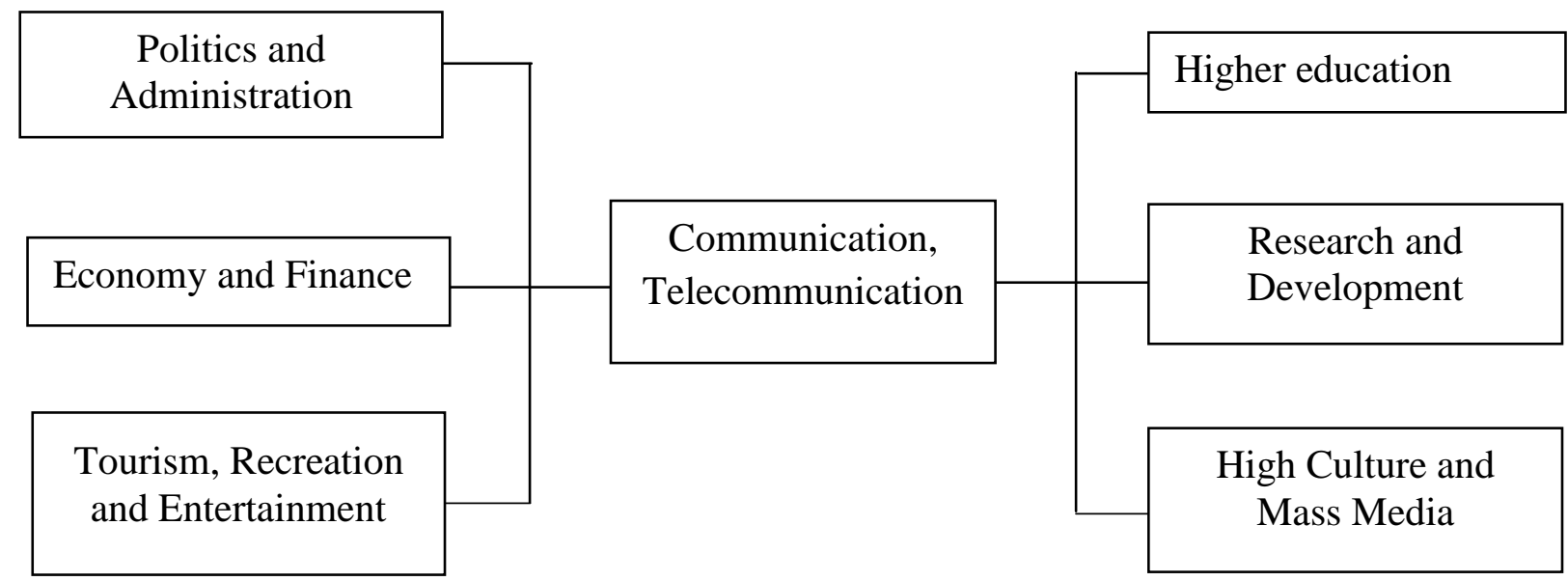

Source: $[12, p .48]$

Fig. 2: Functions of metropolises and their mutual connections

Morphological approach, on the contrary, clearly distinguishes elements forming the structure of a metropolis:

- the central city, called also the central area - metropolis;

- external zone of entities - urbanized and integrated with the central area.

Figure 3 presents the structure of a metropolitan area with a metropolis in its centre. 


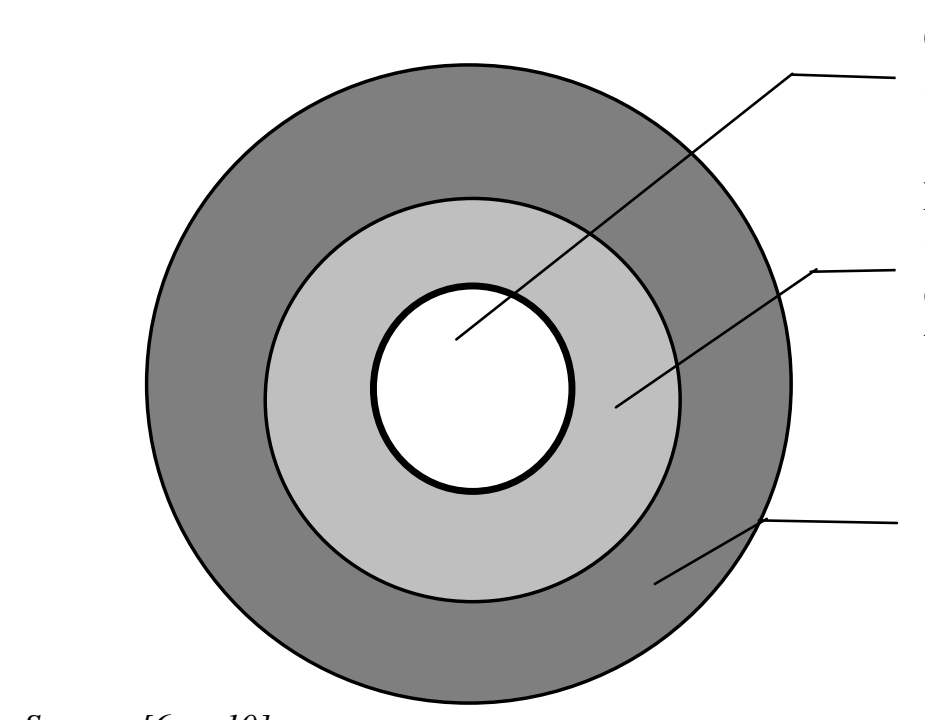

Centre

(big city - metropolis)

External zone

(communes - directly adjacent

or connected by functions with

the metropolis)

Communes in the

metropolitan sphere

of influence

Source: $[6, p .10]$

Fig. 3: Metropolitan area

The central part (the core) of a metropolitan area is a city surrounded by a ring of suburbia, which is frequently associated with a sphere of daytime travel (mostly commuting). The area located outside the suburbia (periphery) serves recreational functions in relation to the metropolis. In addition to the centre and the external zone, there are also communes located within the metropolitan area. They also consist of communes gradually coming to the level of development represented by the communes from within this area. According to the morphological approach, a metropolis as a centre is a part of a spatially continuous urban settlement. It is functionally interrelated with this settlement through an urbanized area characterized by increased intensity of social, economic and spatial conflicts [1].

\section{Conclusions}

Metropolitan cities are bound to attract much more attention in the future since they are one of the features of the contemporary economic landscape. In terms of Poland, where the issues of Metropolitan Act and metropolitan area management are raised with an increasing frequency. What triggers the city's evolution towards a metropolitan city is the process of space metropolitanization. Unquestionably, it brings about unique effects in the form of cities described by R. Florida as spikes of development. One should also acknowledge some negative phenomena accompanying this process, for instance the phenomenon of space discontinuity or belittling the role of the region adjacent to a metropolis. The process of metropolitanization calls forth transformations in the field of regional development. And as this fact is indisputable, questions arise in terms of defining metropolitan cities. Although there are convergent elements in the quoted definitions, a common approach concerning the quantitative criterion required for a metropolitan city has not been adopted yet. Indicating metropolitan functions seems a lot easier - in the sphere of politics, through tourism to mass media. They interweave, extending the influence of metropolitan cities to the surrounding area as well as to the remaining metropolitan centres.

\section{Literature}

[1] HOŁUJ, D.; HOŁUJ, A.: Miasta metropolitalne jako bieguny rozwoju $w$ gospodarce postindustrialnej. [on line]. Bochnia: Wyższa Szkoła Ekonomiczna w Bochni, 2006. [accessed 2015-06-02]. Available from WWW: http://www.wse.bochnia.pl/zn/4-5.pdf 
[2] JAŁOWIECKI, B.: Zarzadzanie rozwojem aglomeracji miejskich. Białystok: Wyższa Szkoła Finansów i Zarządzania w Białymstoku, 2002. ISBN 83-87256-32-3.

[3] JUCHNICKA, M.; PRONIEWSKI, M.: Procesy metropolizacyjne w Polsce metropolizacja przestrzeni. In: Czarnecki, W.; Proniewski, M. (eds.), Metropolitalne problemy rozwoju. Wyższa Szkoła Finansów i Zarządzania w Białymstoku, Białystok, 2009. pp. 13-29. ISBN 987-83-60432-51-8.

[4] ŁUCZYSZYN, A.: Nowe kierunki rozwoju lokalnego ze szczególnym uwzględnieniem peryferyjnych ośrodków w metropoliach. Warszawa: CeDeWu, 2013. ISBN 978-837556-579-9.

[5] MŁODAK, A.: Statystyka metropolii polskich. [on line]. Warszawa: Uniwersytet Warszawski, 2012. [accessed 2015-06-02] Available from WWW: http://www.studreg.uw.edu.pl/pdf/2012_2_mlodak.pdf

[6] NOWAK, J. M.: Polityka przestrzenna $w$ polskich obszarach metropolitalnych. Warszawa: CeDeWu, 2010. ISBN 978- 83-7556-189-0.

[7] PARYSEK, J.: Metropolises and the processes of metropolitanization. [on line]. Warszawa; Polish Academy of Sciences Institute of Geography and Spatial Organization. Geographia Polonica. 2002, Vol. 75, Issue 1, pp. 25-41. [accessed 201506-03] Available from WWW: https://www.geographiapolonica.pl/article/item/7766.html

[8] PASEK, J.: Aglomeracje, metropolie, miasta centralne. Zeszyt Naukowy 17. 2009, Kalisz: Państwowa Wyższa Szkoła Zawodowa im. Prezydenta S. Wojciechowskiego. pp. 7-27. ISBN 987- 83-60137-56-7.

[9] PIĘTA-KANURSKA, M.: Wplyw sektora kreatywnego na ksztaltowanie sie polskich metropolii. Wrocław: UE we Wrocławiu, 2013. ISSN 2084-61-93.

[10] SMĘTKOWSKI, M.: Nowe relacje między metropolia $i$ regionem $w$ gospodarce informacyjnej. [on line]. Warszawa: Uniwersytet Warszawski. [accessed 2015-06-01]. Available from WWW: http://www.studreg.uw.edu.pl/pdf/Sril07/5_smetko.pdf

[11] SMĘTKOWSKI, M.; GORZELAK, G.; KOZAK M.; OLECHNICKA A.; PŁOSZAJ, A.; WOJNAR, K.: Europejskie metropolie i ich regiony. Od obrazu gospodarczego do sieci metropolii. Warszawa: Wyd. Naukowe Scholar, 2012. ISBN 978-83-7383-535-1.

[12] SZCZEPANOWSKA, A.: Cechy i funkcje miast i obszarów metropolitalnych. Zeszyt Naukowy 17. 2009, Kalisz: Państwowa Wyższa Szkoła Zawodowa im. Prezydenta S. Wojciechowskiego. pp. 27-41. ISBN 987- 83-60137-56-7.

[13] SZCZEPANOWSKI, A. E.: Problem ładu przestrzennego w metropoliach. In: Czarnecki, W.; Proniewski, M. (eds.), Metropolitalne problemy rozwoju. Wyższa Szkoła Finansów i Zarządzania w Białymstoku, Białystok, 2009. pp. 57-71. ISBN 98783-60432-51-8.

Agnieszka Humen-Kłyza, M.Sc.Eng. 


\section{METROPOLE JAKO NEJVYŠŠÍ FORMA PROSTOROVÉHO USPOŘÁDÁNÍ ÚZEMÍ}

Stále více pozornosti je věnováno metropolím, což je mimo jiné způsobeno jejich vlivem na změnu paradigmatu ekonomického rozvoje. Cílem prŕspěvku je prezentovat nejvýznamnější otázky problematiky metropole jako územně-strukturálního celku. Východiskem je zde analýza procesu ovlivňujíćího její vznik - procesu metropolizace uskutečněna z hlediska faktorů ovlivňujících jeho začátek a vliv procesu na okolí. Část věnovaná definicím řeší otázku rozdílných pojmů, se kterými se lze setkat v odborné literatuře. Jsou zde prezentovány koncepce rozvoje metropole, její definice, imanentní charakteristiky, které ji odlišují od jiných měst, a také funkce, které metropole plní ve svém okolí.

\section{Die Metropole als DiE hÖChSTE Form DER ORGanisation VON RAUM}

Den Metropolen, die durch ihre Auswirkungen das Paradigma der wirtschaftlichen Entwicklung in beträchtlichem Maße zu beeinflussen im Stande sind, wird immer mehr Aufmerksamkeit gewidmet. Dieser Artikel präsentiert die wichtigsten Aspekte des Themas der Metropole als Form der räumlichen und strukturellen. Ausgangspunkt ist eine Analyse des Prozesses der Bestimmung eines Metropolisierungsprozesses durch das Prisma der Faktoren, die das Auftreten und die Auswirkung des Verfahrens auf die Umwelt bestimmen. Der dem definitorischen Aspekt gewidmete Teil befasst sich mit der Frage der unterschiedlichen Begriffe, denen man in der Fachliteratur begegnet. Es werden hier Entwicklungskonzepte für Metropolen, die Definition, die immanenten Eigenschaften, die sie von anderen Städten unterscheiden, sowie auch die Funktionen vorgestellt, welche die Metropole in ihrer Umgebung erfüllt.

\section{METROPOLIA JAKO NAJWYŻSZA FORMA ORGANIZACJI PRZESTRZENI}

Metropoliom, za sprawą ich wpływu m.in. na zmianę paradygmatu rozwoju gospodarki, poświęca się coraz więcej uwagi. Artykuł ma celu prezentację najistotniejszych aspektów zagadnienia metropolii jako formy przestrzenno-strukturalnej. Jej punktem wyjścia jest analiza procesu determinującego jej powstanie - procesu metropolizacji przeprowadzona przez pryzmat czynników determinujących jego zajście oraz wpływu procesu na otoczenie. Część definicyjna porusza aspekt dysonansu pojęciowego, możliwy do zaobserwowania w literaturze przedmiotu. Przedstawione w niej zostaną koncepcje rozwoju metropolii, jej ujęcia definicyjne, immamentne cechy, które odróżniają je od innych miast, a także funkcje jakie pełni ona $\mathrm{w}$ otoczeniu. 